\title{
Peran Public Relations Membangun Image Pariwisata Bali dalam Erupsi Gunung Agung
}

\author{
I Gusti Ayu Ratna Pramesti Dasih \\ Institut Hindu Dharma Negeri Denpasar
}

\begin{abstract}
Public Relations play a role in the policy order by using two-way communication to support the success of the policy by explaining, informing, maintaining or promoting it to the public so as to create public opinion. Public Relations targets are audiences who have certain communication needs to develop messages that are desired so that they can be communicated. The interaction process of Public Relations aims to create public opinion as an input that is beneficial for both parties. Efforts to instill understanding, foster public motivation and participation, to gain trust and mutual benefit so as to get a good image of the public.
\end{abstract}

Key words: Public Relation, Image, Tourism

\section{Pendahuluan}

Public Relations adalah alat manajemen modern secara struktural merupakan bagian integral dari suatu organisasi. Artinya Public Relations bukanlah fungsi terpisah dari fungsi organisasi atau bersifat melekat pada manajemen perusahaan. Public Relations dapat menyelenggarakan komunikasi dua arah secara timbal balik antara organisasi yang diwakilinya dengan publiknya. Peran Public Relations disini turut menentukan sukses tidaknya visi, misi dan tujuan bersama dari organisasi. Aktivitas komunikasi pada manajemen organisasi atau perusahaan seperti hotel biasanya diserahkan dan dilaksanakan sepenuhnya oleh pihak Public Relations. Fungsi Public Relations dalam manajemen perusahaan seperti hotel, secara umum aktivitasnya sebagai : 1) Communicator, 2) Relationship, 3) Back up Management, dan 4) Good Image Maker.

Aktivitas komunikasi seorang Public Relations harus didukung oleh hubungan yang baik dengan media dan pers. Karena hubungan dengan media dan pers (Media dan Press Relations) merupakan alat pendukung atau media kerja sama untuk kepentingan pross publikasi dan publisitas berbagai kegiatan program kerja atau untuk kelancaran aktivitas komunikasi Public Relations dengan pihak publiknya. Hubungan media dan pers dalam Public Relations sebagai saluran (channel) penyampaian pesan, maka upaya peningkatan pengenalan (awareness) dan informasi atau pemberitaan dari pihak publikasi menjadi prioritas utama. 
Karena salah satu fungsi pers adalah kekuatan dalam pembentukan opini publik yang sangat efektif melalui media massa.

Melalui media massa, kerja sama dengan pers akan menghasilkan frekwensi publisitas yang cukup tinggi. Sehingga dampak pemberitaan akan bersifat stimultaneity effect (efek keserempakan), efek dramatisir atau efek publisitas tinggi, dan memiliki pengaruh yang luar biasa besarnya terhadap pembentukan opini publik dalam waktu relatif singkat dengan jumlah pembaca atau audiensi yang tersebar di berbagai tempat atau kawasan dalam waktu bersamaan. Hal ini sangat dirasakan oleh pengelola industri pariwisata di Bali, ketika terjadinya bencana erupsi Gunung Agung. Dampak pemberitaan yang sangat hebat menghantam dunia pariwisata Bali, akibat dari opini publik yang berkembang sangat cepat. Penurunan jumlah kunjungan wisata baik domestik maupun international terjadi sangat drastis, sehingga membuat pelaku pariwisata di Bali kalang kabut menghadapi efek publisitas yang tinggi akibat dari pemberitaan yang belum tentu kebenarannya, yang lebih dikenal dengan efek dari berita hoax. Peran Public Relations sangat penting dalam membangun kembali image dan goodwill pariwisata Bali agar kembali normal.

\section{Pembahasan}

Public Relations menjalankan fungsi dan tujuan manajemen untuk menunjang fungsi kegiatan manajemen perusahaan berdasarkan pencapaian tujuan yang onjektif atau disebut dengan istilah management by objective, secara efisien dan efektif melalui proses komunikasi yang terencana baik ke dalam maupun keluar perusahaan. Hubungan yang baik wajib dijalin seorang Public Relations dengan publiknya untuk mencapai tujuan yang spesifik berlandaskan saling pengertian (mutual understanding) dan saling mendukung (mutual supporting).

Management by objective merupakan proses dimana Public Relations secara bersama-sama mengidentifkasikan tujuan umum perusahaan, termasuk menetapkan kawasan tanggung jawab setiap divisi untuk merencanakan target capaian yang diharapkan. Management by objective dimulai dari komitmen top manajemen untuk men-setting dan me-review perencanaan dan tujuan utama perusahaan. Jaringan-jaringan komunikasi yang dibangun oleh seorang Public Relations meliputi opinion leader, gate keepers, cosmopolites, bridge, liaison, dan isolate. Sedangkan strategi yang diterapkan oleh seorang Public Relations menurut Cutlip (dalam Ruslan, 2007:122-123) yakni : 1) Credibility (kredibilitas), 2) Contex (konteks), 3) Content (Isi), 4) Clarity (kejelasan), 5) Continuity and Consistency (kontinuitas dan konsistensi), 6) Channels (saluran), dan 7) Capability of the Audience (kapabilitas khalayak).

\section{Opini Publik}

Opini publik adalah kumpulan pendapat individu terhadap masalah tertentu yang mempengaruhi khalayak. Salah satu fungsi public relations adalah menjaga hubungan yang harmonis antara organisasi/perusahaan dengan public yang akan menciptakan opini public. Semakin banyak memiliki relasi, akan semakin mudah memunculkan opini public. Artinya, perbaikan maupun perkembangan organisasi/perusahaan bisa lebih efektif karena kebutuhan dan keinginan public akan mudah direalisasikan secara tepat. Opini public identik dengan keterbukaan dalam mengungkapkan ide, pendapat, keinginan, kebutuhan, keluhan, kritik yang 
membangun dan kebebasan dalam penulisan. Dengan kata lain, opini public merupakan efek dari kebebasan dalam mengungkapkan ide-ide dan pendapat, opini public harus mampu mempengaruhi media untuk menciptakan opini public. Opini public jika ditanggapi dengan tepat, objektif, jujur, transparan dan didasarkan pada fungsi manajemen, umumnya akan membawa perubahan. Ini menunjukkan adanya perkembangan organisasi/perusahaan dan opini public sebagai efeknya. Opini public muncul karena adanya kepercayaan yang kuat, saling percaya untuk perbaikan produk atau jasa yang secara otomatis akan terjadi perbaikan pada organisasi/perusahaan sehingga pada akhirnya akan memberikan keuntungan bagi semua pihak. Opini public diciptakan secara terus menerus sehingga public akan memperoleh gambaran yang jelas tentang organisasi/perusahaan. Kepercayaan public akan menimbulkan goodwill pada organisasi/perusahaan sehingga citra positif akan berkembang.

Opini dapat dinyatakan secara aktif atau pasif, verbal ataupun secara terbuka melalui ungkapan kata-kata yang dapat ditafsirkan dengan jelas dalam pilihan kata halus atau diungkapkan secara tidak langsung dan dapat diartikan secara konotatif atau persepsi (personal). Opini juga dapat dinyatakan melalui perilaku, sikap, tindakan, mimik muka atau bahasa tubuh yang berbentuk simbol-simbol tertulis seperti pakaian yang dikenakan atau makna sebuah warna. Untuk memahami opini bukan hal yang mudah karena memerlukan kepercayaan (belief) dan sikap (attitude) mengenai sesuatu. Opini juga terbentuk karena proses pemberian makna untuk menjaring khalayak dengan latar belakang budaya, kebiasaan dan adat istiadat yang dianut oleh masyarakat. Pengalaman masyarakat akan menjadi landasan cara pandang dalam menyikapi berita atau informasi baru yang berkembang. Nilai, norma dan etika juga membentuk cara pandang masyarakat dalam menerima informasi sehingga berita-berita yang berkembang mempunyai pengaruh terhadap opini publik dalam mengartikan berita-berita yang dipublikasikan agar tidak dirugikan dengan berita hoax.

Seperti halnya, saat kejadian bencana erupsi Gunung Agung. Informasi yang simpang siur membuat masyarakat merasa khawatir. Tidak hanya masyarakat sekitar yang berdampak langsung pada bencana erupsi Gunung Agung, namun juga sangat mempengaruhi kenyamanan para wisatawan yang sedang berkunjung di Bali. Berita yang tersebar begitu cepat terutama di media online membuat keresahan bagi wisatawan sehingga banyak memilih untuk kembali secepatnya ke negaranya. Penurunan jumlah kunjungan wisata juga dikarenakan pembatalan dari travel agent karena ketakutan orang untuk berwisata ke Bali karena adanya erupsi Gunung Agung. Pariwisata Bali mengalami keterpurukan akibat berita hoax yang belum tentu kebenarannya. Opini public terbentuk karena kemudahan masyarakat untuk memperoleh informasi seluas-luasnya melalui media terutama media online. Namun berdasarkan pengalaman sebagai landasan cara pandang masyarakat maka berita yang dipublikasikan mampu menjaring opini public sehingga hotel, restaurant, travel dan sarana pendukung pariwisata lainnya mengalami penurunan omzet.

Public Relations mempunyai peran penting bagi perusahaan karena sangat berpengaruh dalam menjaga hubungan serta membangun image untuk mendapatkan kepercayaan dari khalayak. Public Relations di perusahaan yang 
bergerak di bidang pariwisata seperti hotel banyak yang mengambil strategi untuk memperbaiki reputasi dan citra pariwisata Bali dengan mengajukan permohonan melaksanakan sale mission ke negara-negara yang tingkat kunjungan wisata ke Bali sangat tinggi dan sudah menjadi pangsa pasarnya. Peran Public Relations semakin tinggi aksesnya dengan asumsi untuk membangun citra positif terhadap pariwisata Bali pada umumnya sehingga output yang diharapkan dapat meningkatkan kunjungan wisatawan ke Bali dan hotel atau sarana yang mendukung pariwisata lainnya sehingga omzet terpenuhi. Dalam menjalankan sale mission, Public Relations menjadi komunikator dan mediator bagi perusahaannya juga harus mampu menjamin audiens sebagai bentuk tanggung jawab sosialnya, diekspresikan melalui hubungan yang saling menguntungkan antara perusahaan dengan publiknya (mutual benefit relationship).

\section{Peran Pembangun Image}

Public Relations dalam menjalankan perannya untuk membangun image dan goodwill menggunakan khalayak sebagai salah satu komponen utama dari perusahaan. Upaya Public Relations dalam mendeskripsikan perusahaan yang bergerak dalam pariwisata di Bali kepada khalayak, supaya diketahui dan dipahami bahwa perusahaan memiliki goodwill dan tanggung jawab sosial ditunjukkan melalui input-process-output. Upaya ini sering disebut dengan istilah interpreting management to the publics. Public Relations juga sebagai jembatan komunikasi antara perusahaan dengan publiknya untuk mengetahui respon yang dihasilkan termasuk dalam proses distribusi dan pasca layanan kepada public, hal ini sering disebut dengan interpreting public to the management. Upaya Public Relations dalam mengembalikan citra pariwisata Bali terlihat dari usahanya dalam sale mission yang dilakukan secara continue untuk memenuhi target dan omzet perusahaan.

Tanggung jawab sosial terhadap isu yang relevan merupakan kekuatan bagi seorang Public Relations dalam menjalankan visi, misi dan tujuan perusahaan untuk mendapatkan sokongan (goodwill) dari khalayak. Ekspresi dari tanggung jawab sosial dinyatakan secara aktual melalui serangkaian program kegiatan yang bertujuan untuk membantu, mendorong dan mendidik public yang relevan untuk memperoleh respon serta mampu mengembangkan opini public demi kemajuan perusahaan serta terbangunnya kembali citra positif bagi pariwisata di Bali. Semua komponen pariwisata Bali harus memiliki kepedulian yang tinggi terhadap kemungkinan akses yang timbul akibat adanya proses produksi yang dilakukan serta kepekaan terhadap isu-isu lingkungan baik dalam skala global maupun domestik tidak hanya terbebankan pada peran Public Relations saja. Karena citra pariwisata Bali wajib dijaga oleh semua komponen pariwisata dan masyarakat Bali.

Pengembangan citra yang strategis berasal dari dua belah pihak yaitu perusahaan (yang diwakili oleh Public Relations) dan public. Loyalitas perusahaan melalui peran Public Relations menjadi satu hal yang penting dalam upaya membangun image dari pandangan public. Dalam menjalin hubungan dengan public, sikap loyalitas ditunjukkan oleh Public Relations yang memiliki komitmen tinggi untuk bisa mempengaruhi khalayak yang potensial untuk kemajuan perusahaan serta menumbuhkan kembali image dan goodwill. Public Relations juga berperan 
dalam menjaga image untuk menjamin khalayak menerima pelayanan yang baik sehingga merasa puas terhadap transaksi yang sudah dilakukannya. Kepuasan public sangat membantu promosi dan menumbuhkan image sehingga goodwill akan terwujud.

Proses awal dari loyalitas dapat dilihat dari sikap public terhadap perusahaan. Sikap ini biasanya melalui beberapa tahapan yang dimunculkan oleh public yakni : dimulai dari rasa suka (liking) kemudian diikuti sikap hormat (respect). Apabila public mulai menunjukkan kedua sikap ini, biasanya akan muncul tahapan selanjutnya yang lebih dalam seperti kognitif yaitu sikap yang ditunjukkan oleh public bahkan menjalin persahabatan (friendship) selanjutnya tahap akhir ditunjukkan dengan kepercayaan (trust). Kepercayaan yang dimaksud adalah kepercayaan public kepada perusahaan akibat relasi dan interaksi yang telah terbentuk. Pada tahapan ini, afektif memiliki peranan yang sangat besar dalam membentuk kepercayaan public terhadap perusahaan. Atas kepercayaan public terhadap perusahaan maka perusahaan yang dwakili oleh Public Relations wajib memberikan reward kepada pelanggan atau relasi. Kesuksesan peran Public Relations dalam membangun image dan menumbuhkan goodwill dengan prinsip kerja "good business is good service dan good business is good relations".

Aktivitas utama Public Relations dalam menumbuhkan image dan goodwill pariwisata di Bali berada di posisi yang sedekat mungkin dengan pimpinan puncak perusahaan. Peran Public Relations dalam upaya memerangi berita hoax dengan menggali informasi sebanyak-banyaknya yang dapat menguntungkan perusahaan. Disamping itupula, Public Relations berfungsi untuk mempertahankan visi dan misi perusahaan agar jauh dari prasangka buruk agar tercipta citra positif di hadapan khalayak (corporate image maintenance). Strategi komunikasi sirkuler yang digunakan oleh Public Relations untuk bekerjasama dalam merancang produk-produk agar bisa dipublikasikan sehingga menarik perhatian khalayak. Sehingga bisa mencapai manfaat yang diinginkan dari proses kedekatan tersebut adalah sebagai berikut :

a. Pengetahuan yang rinci mengenai sistem terpadu, pola perencanaan, kebijaksanaan, keputusan yang diambil, visi dan arah tujuan perusahaan untuk menghindari terjadinya kesalahan dalam penyampaian pesan dan informasi dari perusahaan kepada publiknya.

b. Public Relations sebagai komunikator dan mediator, harus mengetahui sejauh mana batasan pesan dan informasi yang dapat dipublikasikan, atau yang tidak bisa diungkapkan secara terbuka kepada public khususnya kepada kalangan pers atau media massa.

c. Aktivitas Public Relations dapat dipertegas dengan batasan wewenang dan tanggung jawab dalam memberikan keterangan secara jelas terhadap pelaksanaan keputusan atau kebijaksanaan pimpinan perusahaan.

d. Public Relations harus mengetahui secara langsung dengan tepat tentang latar belakang suatu proses perencanaan, kebijaksanaan, arah hingga tujuan perusahaan yang hendak dicapai baik jangka pendek maupun jangka panjang.

e. Public Relations berhubungan secara langsung dengan puncak pimpinan, tanpa melalui perantara departement lain. Maka fungsi Public Relations 
berlangsung secara optimal, antisipatif dan dapat melaksanakan berbagai macam perencanaan.

f. Public Relations berperan melakukan tindakan mulai dari memonitor, merekam, menganalisis, menelaah hingga mengevaluasi setiap reaksi, khususnya dalam upaya penilaian sikap dan tindakan serta mengetahui persepsi masyarakat atau dalam upaya mendapatkan feedback.

g. Public Relations secara langsung memberikan saran, ide dan rencana tentang program kerja untuk memperbaiki atau mempertahankan nama baik, kepercayaan dan citra perusahaan terhadap publiknya. Termasuk upaya menjembatani atau menyerasikan antara kebijaksanaan dengan keputusan perusahaan berdasarkan kepentingan dan keinginan sekaligus upaya memperoleh dukungan dan partisipasi dari public.

Berdasarkan manfaat yang ingin dicapai, maka strategi Public Relations untuk menciptakan iklim yang kondusif dalam mengembangkan tanggung jawab serta partisipasi dengan khalayak untuk mewujudkan tujuan Bersama yakni membangun image dan goodwill pariwisata di Bali. Strategi yang digunakan oleh Public Relations sebagai berikut : 1) strategi operasional, 2) pendekatan persuasif dan edukatif, 3) pendekatan tanggung jawab sosial, 4) pendekatan kerja sama, dan 5) Pendekatan koordinatif dan integratif. Melalui pelaksanaan program Public Relations yang dilakukan dengan pendekatan kemasyarakatan melalui mekanisme social cultural dan nilai-nilai yang berlaku di masyarakat, maka opini public dapat dilihat pada media massa. Artinya Public Relations mutlak bersikap dan memiliki kemampuan untuk mendengar.

Fungsi Public Relations adalah menciptakan komunikasi dua arah atau timbal balik dengan menyebarkan informasi dari perusahaan kepada public yang bersifat mendidik dan melakukan pendekatan persuasif agar tercipta saling pengertian, menghargai, pemahaman dan toleransi untuk membangun image dan goodwill pariwisata di Bali. Dalam menumbuhkan sikap tanggung jawab sosial maka tujuan dan sasaran yang hendak dicapai bukan ditujukan untuk mengambil keuntungan sepihak dari public sasarannya namun untuk memperoleh keuntungan bersama. Public relations wajib mensosialisasikan misi perusahaan yang diwakilinya agar diterima dan mendapat dukungan public. Hal ini dilakukan dalam rangka menyelenggarakan hubungan baik dengan publiknya dan memperoleh opini public serta perubahan sikap yang positif bagi kedua belah pihak. Public Relations juga berupaya membina hubungan yang harmonis antara perusahaan dengan berbagai kalangan baik eksternal maupun internal untuk meningkatkan kerja sama.

Untuk memperluas peran Public Relations membangun image dan goodwill pariwisata Bali di masyarakat, maka fungsi dalam arti sempit hanya mewakili perusahaan, sedangkan yang lebih luas adalah berpartisipasi dalam menunjang program pembangunan nasional dan mewujudkan ketahanan nasional di bidang politik, ekonomi, sosial budaya dan hankamnas. Berkaitan dengan hal tersebut, strategi komunikasi Public Relations dalam upaya menjalin berbagai hubungan positif dengan public internal dan eksternal yakni dengan : 1) menginformasikan (to inform), 2) menerangkan (to explain), 3) menyarankan (to suggest), 4) 
membujuk (to persuade), 5) mengundang (to invite), dan 6) meyakinkan (to convince).

Perkembangan aktivitas Public Relations dalam usaha menumbuhkan image dan goodwill pariwisata Bali menerapkan sinergi dari fungsi pemasaran dan manajemen Public Relations yakni Marketing Public Relations yang berpotensi mendukung proses promosi dan publikasi dengan jangka waktu yang relatif singkat. Marketing Public Relations sangat efektif dan efisien dalam penyebaran pesan dan informasi. Marketing Public Relations memiliki kekuatan membujuk (persuasive approach) dan mendidik khalayaknya (public educated) serta didukung kecanggihan media elektronik, seperti halnya sale mission yang dilakukan oleh Public Relations di hotel-hotel berbintang di Bali. Sale mission dilakukan dengan mendatangi negara-negara yang menjadi sumber wisatawan dan menggelar pameran dengan memasarkan pariwisata Bali dan perusahaannya.

Marketing Public Relations yang diterapkan ketika melaksanakan sale mission untuk mengembalikan kepercayaan khalayak. Interaksi secara langsung memberikan pengaruh yang efektif dan efisien dalam menjaring opini public. Marketing Public Relations memiliki kekuatan sinergi untuk menjembatani hambatan yang terjadi dalam penyampaian pesan dan informasi yang diselaraskan. Sehingga pesan yang disebarluaskan dapat mempengaruhi opini public yang awalnya sempit menjadi terbuka sesuai dengan selera komunikannya. Marketing Public Relations juga dapat membangun kepercayaan khalayak lebih cepat sehingga manfaat dari produk-produk yang ditawarkan terpenuhi. Marketing Public Relations juga berperan memberikan peluang untuk memenuhi target dan sasaran yang direncakan. Marketing Public Relations memberikan pelayanan prima melalui : 1) customer value, 2) cost to customer, 3) convenient for the customer, dan 4) communication. Nilai-nilai konsumen termasuk kebutuhan dan keinginannya untuk diperhatikan selain menggantikan nilai atas unsur produknya. Yakni biaya yang ditanggung oleh konsumen berupa harga dan waktu serta tenaga yang dibutuhkan untuk memperoleh produk tersebut. Kemudahan memperoleh produk bagi konsumennya merupakan komponen komunikasi dua arah (timbal balik) yang merupakan suatu dialog dan akan menggantikannya pada unsur promosi.

\section{Simpulan}

Public Relations menuntut kepekaan terhadap kecendrungan dan peristiwa. Sebab, Public Relations harus mampu menarik perhatian khalayak yang bertife ekstrover yakni memiliki kecendrungan melihat keluar dari pada dirinya sendiri. Public Relations harus memiliki kemampuan menerima pendapat orang lain, serta memiliki keberanian untuk mendengar, sabar dan mau menerima kritikan. Masalah manajemen perusahaan dapat ditelusuri dari kegagalan komunikasi, sehingga menuntut kepekaan terhadap keberadaan manusia, kebutuhan dan minatnya. Penyebab kegagalan komunikasi karena kurangnya intensitas dalam mengkomunikasikan informasi sehingga mengakibatkan keterlambatan dalam segala lini. Peran Public Relations sebagai komunikator maupun mediator sangat mempengaruhi terciptanya image dan goodwill. Pariwisata Bali mengalami keterpurukan akibat informasi melalui pemberitaan media online yang belum tentu kebenaran sehingga terjadi kecemasan pada khalayak. Sumber berita tidak 
jelas sehingga tergolong dalam berita hoax. Public Relations harus memiliki kemampuan menerima pesan masing-masing individu yang berbeda, karena senatiasa akan mempengaruhi secara langsung pengambilan keputusan.

Daftar Pustaka

Ardianto, Elvinaro. 2009. Public Relations Praktis. Bandung : Widya Padjadjaran.

Darmastuti, Rini. 2006. Etika PR dan E-PR. Jogjakarta : Gava Media.

Jefkins, Frank dan Daniel Yadin. 2009. Public Relations Edisi Lima. Erlangga.

Kusumastuti, Frida. 2001. Dasar-Dasar Humas. Jakarta : Ghalia Indonesia.

Ruslan, Rosady. 2006. Manajemen Public Relations Dan Media Komunikasi. Jakarta : Raja Grafindo Persada.

Simandjuntak, John P. dkk. 2009. Public Relations. Graha Ilmu. 